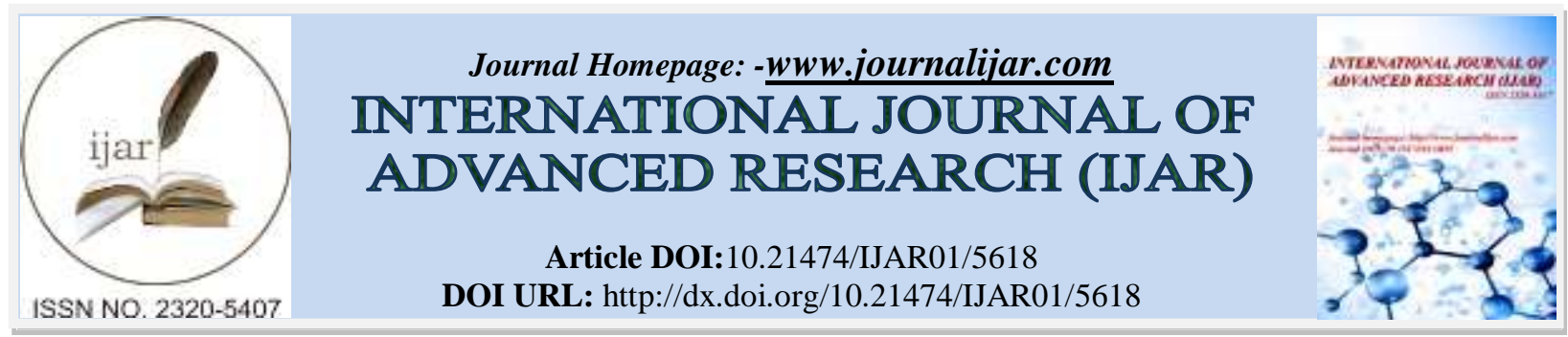

RESEARCH ARTICLE

\title{
CHANGING ROLES OF WOMEN WITH TIME.
}

\author{
Ayuta Mohanty ${ }^{1}$ and Puspita Das ${ }^{2}$. \\ 1. Guest Faculty in English, Rajdhani College, Bhubaneswar. \\ 2. Associate Professor, College of Home Science, CAU, Tura, Meghalaya.
}

\section{Manuscript Info}

Manuscript History

Received: 14 August 2017

Final Accepted: 16 September 2017

Published: October 2017

Key words:-

Changing, Roles, Women, Gender,

Patriarchy, Identity

\section{Abstract}

In India women have always suffered due to the patriarchal mindset. They have been discriminated since time immemorial. Since ancient times they had been following the roles assigned to them by the society- the role of a house-maker. The women were always expected to remain within the boundaries of their home and take care of their families. They had no identities of their own. Due to this patriarchal setup they have suffered a lot. However, with the passage of time, she has started identifying the latent power and potentials within herself. Women are trying to empower themselves and establish their identity to leave behind themselves their old marginalized lives. With time, Indian women have started to take small steps to empower themselves. They have begun to step into the frame. The four walls of her home can no longer hold her. She has developed the courage to step out of her house and face the world to create her own identity and live for herself. The Indian women are making themselves capable to stand on their own feet without depending on any man- be it there fathers, brothers, husbands or sons- for their status or power. Women have started realizing the hidden power in them. In a man's world they are trying their best to give a tough fight to men. This article focuses the journey of the changing roles of women from submissive house keepers to empowered women creating her own identity through the eyes of two Indian authors- R. K. Narayan and Shashi Deshpande. R.K. Narayan's The Dark Room portrays the beginning of this journey through its central character Savitri which is taken to another level by Daisy in R.K. Narayan's The Painter of Signs where Daisy is seen as a symbol of change in the role of women in coming time and the journey reaches its zenith in Shashi Deshpande's The Matter of Time where the motherdaughter duo Sumi and Aru sets an example that whatever the situation may be, women have the power to build themselves and overcome all the hurdles of their life. They go on to prove that women are not just made to manage their homes but they can create their own identity and break these stereotypical gender roles assigned by the society.

Copy Right, IJAR, 2017,. All rights reserved. 


\section{Introduction:-}

India, a traditionally male-dominated society, subordinates individual rights to roles assigned by society. Since ancient times, women and men have been assigned some roles by the society which they must fulfil. The boundaries of these roles were not to be breached. The men were assigned the role of bread winners and women the homemakers. The women were expected to stay within the four walls of their house and take care of the domestic needs of the family whereas the men would take care of the outside matters. Due to this division of labour, women expected to remain meek, docile, subservient and obedient to their husbands. They were identified as someone's daughter, someone's sister, someone's wife and someone's mother. They had no identity of their own. Postindependence, when India acquired her own identity, women too started struggle to acquire their own identities. They struggled to break the stereotypical roles that were assigned to them by the society. They tried to break the boundaries that defined the division of labour between men and women. They started stepping out of their homes to try different roles by which they were able to create their own identities and these changing roles with time helped them to move forward in their journey of women emancipation. They proved before the society that they are no less than their male counterparts. They can simultaneously manage the home and earn livelihood for their family.

The Dark Room (1938) is one of R.K. Narayan's early novels, written before India achiever her independence. The protagonist of the novel, Savitri, is a typical Indian middle class housewife. Her husband Ramani was a very insensitive man. He was working as an insurance employee in an insurance company. Savitri was a submissive and obedient wife. Ramani always dominated and neglected her. For Ramani, Savitri is just a means of gratifying his needs and desires. According to him, a woman's primary duty (also a divine privilege) was being a wife and a mother. Whenever Savitri was unable to endure Ramani's tyrannical and inhuman behaviour, she took refuge in 'the dark room', where she lies silently with her face to the wall; it is her 'dark room'. The dark room was a store room where all the unnecessary things of the house were stored. She identified herself with useless domestic junks which have outlived its utility. This dark room is not only a room but also a metaphor which highlights the miserable condition of a woman and the oppression imposed upon them by men. But her husband never cared about her being in the dark room. According to Ramani, the women's place lies inside their homes where they just need to fulfil their duties as a wife and a mother and remain obliged to their husbands who provide them the money for sustainability. He never appreciates Saviti's efforts as a good wife and a good mother. Rather whenever the children did something wrong or he got displeased by anything in the home, he heaps all the blame on Savitri and scolded her for her incapability in managing just the home and criticised her for doing nothing while he manages everything so well outside the home. He never counted all the works that Savitri did all the day as work. For him earning the livelihood was the major work. Even though Savitri left her home to have an independent existence, the societal setup did not let her succeed in her attempts and she returned back to her home but a part of her, the obedient part, had died. She was the forerunner of the change in the roles of women that was to follow.

The Painter of Signs (1976) by R.K.Narayan depicts the little change in the roles of women that started in postindependence era. In The Painter of Signs, Narayan explores the theme of women's quest for identity through the real protagonist of this novel, Daisy, a champion of women's rights, who asserts woman's independent entity and advocates the norms of small families to solve India's population problem. Daisy was a strong minded young woman who did her work with missionary zeal. She carried a sense of intense conviction to her work, which made her sacrifice everything else in her life to identify herself totally to her work. According to Raman, she was like a yogi with his eyes fixed on the centre of his nose, seeing nothing else in life.

Daisy suggests symbolically the coming signs of change in the role of women in the world of a small town, Malgudi, and in India. Daisy, the family planning worker is a liberated woman in many respects- as a spirited adolescent, she has carved out a career for herself; established her identity; and gained economic security and emotional strength. Daisy's energy, zeal, and dogged persistence evoke admiration from the reader. Daisy was quite unconventional for the society who was ready to break the traditional and stereotypical norms designed by the society for women. She never accepted anything that denied her independent existence.

In one of his interviews by S. Krishnan, Narayan himself says " to show her complete independence and ability to stand by herself, I care not to give her a name with any kind of emotional connotation, I am calling her simply Daisy. She is a very strong character." Thus, in The Painter of Signs, Daisy paints the new signs and new footmarks wiping out the old ones about the role of women in society. Finally, The Painter of Signs comes echoing the voices of all women, who had strived to come out and have an independent existence. 
Shashi Deshpande effectively portrays, in her novels, modern, educated middle-class women facing conflicts between patriarchy and independent identity. The women in her novels are oppressed and subjugated by the patriarchal ideology but they strive hard for asserting their rights and to establish their own identity. A Matter of Time (1996) by Shashi Deshpande traces the journey of Sumi and her daughter Aru where Sumi tries to make her own identity and Aru puts up a brave fight against patriarchy. The novel starts when Gopal, Sumi's husband, suddenly walks out of her life for a reason that even he is not able to explain. Gopal's desertion leaves Sumi and her three daughters- Aru, Charu and Seema in utter shock and disappointment. Sumi, with her daughters, returns to her parent's house. Without Gopal, Sumi feels incomplete and despair envelops her. But she does not let despair and disappointment to break her. Rather she uses the situation to show a great strength to move on in her life for herself and for the betterment of her daughters. She decides to become independent for herself and for the upbringing of her daughters. She joins a job in a school and learns to ride a scooter. Not only this, she also discovers a talent hidden in her for so long- the talent of writing. She starts writing plays for her students and her play gets much appreciation which motivates her to write more. She refuses to take any financial help from her father and Ramesh (Gopal's nephew). She struggles hard to fulfil all needs of her daughters but never takes any financial help or sympathy from anyone. She stands strong hiding all her pain, humiliation, obscurities and dilemmas within herself. She proves one of the major feminist ideologies that to leave behind the marginalized lives, women need to be economically independent. When she got a job in a different city and she decided to go there with Seema, Aru asked her how she can go, to which Sumi replies, "Be happy for me, Aru. This is the first thing in my life I think I've got for myself." (Deshpande 230) Her reply makes Aru realize that after all the hardships and sacrifices her mother had done for them, it is time that her mother should do something for herself which gives her peace and happiness.

Aru, Sumi's daughter, represents another facet of the modern woman- independent, revolting and standing up for what is right. When Sumi was trying to establish her identity, Aru tried to stand up for women's right against patriarchal ideals. She is very practical in viewing her life. She does not prefer suffering silently. She decided to fight against patriarchy and to become a lawyer. She also participated in social services in her free time and stood for injustice against women. She discarded marriage and motherhood as the major part of women's identity. Aru also tried to be the support or "man of the family" (Deshpande 36). She accompanied her mother to dentist, took utmost care of her baby sister Seema, and did most of the chores of the house so that her younger sister Charu could focus on her studies. "She wants to take Gopal's place, she wants to fill the blank Gopal has left in their lives." (Deshpande 36). Aru tried her best to help her mother and sisters to pass through the storm that had surrounded their lives.

In an unfortunate accident, Sumi and her father Shripati died leaving the family grief stricken. But Aru tries to be strong infront of everyone, consoling her sisters and Kalyani. When she sees her grand mother broken she rushed near her and said, "Amma, I'm here, I'm your daughter Amma, I'm your son, I'm here with you, I'm here."(Deshpande 233). In the end when Gopal visits them, Aru tells him to go and not to worry about them. She also tells him that they will be alright. In Aru reflected Sumi's strength to stand for her family. Aru stood strong as a support system, supporting and protecting her grandmother and her sisters just as sons are expected to do in a patriarchal society. Aru and Sumi made an attempt to break the mould designed for women in a patriarchal setup and faced all challenges that came before them to gain their deserving place in the society. They became the definition of the high levels of changing roles of women.

Savitri started the struggle against the stereotypical roles for women set by the society, Daisy took the fight to another level and through Aru and Sumi, the struggle reached almost to its zenith. This paper analyses how the roles of women in a society changes over a period of time. When a society develops with time, its old stereotypical roles and ideals should also shed its skin and become brand new. Then only India can become a developed country and achieve emancipation and liberation of women in its true sense.

\section{References:-}

1. Deshpande, Shashi. A Matter of Time. Gurgaon: Penguin Books, 1996. Print.

2. Gupta, Ashish. "A Matter of Time: The Quest for Female Identity." Galaxy:International Multidisciplinary Research Journal I.III (2012): n. pag. Web. 05 Nov. 2016.

3. Narayan, R.K. The Dark Room. Chennai: Indian Thought Publications, 2013. Print.

4. Narayan, R.K. The Painter of Signs. Chennai: Indian Thought Publications, 2013. Print. 